2. Vogl S. Soziale Gesetzgebungspolitik, freie Rechtsfindung und soziologische Rechtswissenschaft bei Eugen Ehrlich. Baden-Baden: NomosVerl.-Ges., 2003. 396 S.

3. Ehrlich E. Grundlegung der Soziologie des Rechts. 4. Aufl., durchges. u. hrsg. von Manfred Rehbinder. Berlin: Dunker und Humblot, 1989. 441 S.

4. Ehrlich E. Die juristische Logik // Archiv für die civilistische Praxis. 1917. № 115. S. 125-439.

5. Ehrlich E. Die juristische Logik. Tübingen: Mohr, 1918. VII, 337 S.

6. Pavčnik M. Juristisches Verstehen und Entscheiden: vom Lebenssachverhalt zur Rechtsentscheidung; ein Beitrag zur Argumentation im Recht. Wien: Springer, 1993. X, 182 S.

7. Kaufmann A. Analogie und «Natur der Sache», zugleich ein Beitrag zur Lehre vom Typus. 2. Aufl. Heidelberg Hamburg: v. Decker, 1982. XIII, 88 S.

DOI https://doi.org/10.30525/978-9934-26-148-0-11

\title{
ЧУМАЦТВО ЯК ЗАСІБ ПЕРВІСНОГО НАГРОМАДЖЕННЯ КАПІТАЛУ В УКРАЇНІ
}

\author{
Сокур Ю. В. \\ кандидат юридичних наук, дочент, \\ доцент кафедри історії держави та права \\ Національної академії внутрішніх справ \\ м. Київ, Украӥна
}

Торгівля - найдавніша сфера людської діяльності, яка виникла одночасно із виробленням матеріальних благ. Все, що створюється руками людини, призначене або для задоволення власних потреб (натуральне виробництво), або, - 3 виникненням товарного господарства, - для обміну чи продажу іншому споживачеві.

Від давніх давен торговельна діяльність була надзвичайно поширена і на українських землях. Цьому сприяло, зокрема, вдале географічне розташування країни - на перетині цивілізацій і комунікаційних шляхів між північчю й півднем, між сходом і заходом [1].

Торгівля і транспорт в усі часи і понині була обов'язковою передумовою повноцінного функціонування економіки. Торгівля неможлива без транспортування товарів від виробника до споживача. Цю функціональну роль виконувало чумацтво як унікальне явище, притаманне саме Україні. 
Із збільшенням населення України, розширенням території, на якій торгували чумаки, i, нарешті, зі збільшенням прейскуранту чумацьких товарів розміри чумацького промислу і його значення в економіці України весь час зростали. Доступні нам відомості про чумацтво в XVIII столітті дають підставу вважати, що на значній території України після землеробства і скотарства чумацтво стало найважливішим заняттям населення, а в окремих населених пунктах відігравало більшу роль, ніж навіть землеробство.

Значне зростання внутрішньої і зовнішньої торгівлі супроводжувалось збільшенням обсягу перевезень товарів, що викликало дедалі більшу потребу в обсягах транспорту. Розвиток внутрішньої і зовнішньої торгівлі збільшував потребу в дешевих транспортних засобах. Це було основною причиною швидкого поширення 3 кінця XVIII століття чумацького візництва, яке найбільше відповідало вимогам торгівлі. Основною перевагою чумацького візництва була його відносна дешевизна. 3 винайденням залізниці ця перевага себе вичерпує.

При всій різноманітності товарів, які транспортували, якими торгували українські чумаки, головним для них в усі часи все-таки залишалась сіль. Тут вони були свого роду монополістами і не мали собі конкурентів. Слід зазначити, що в минулі часи сіль вважалася стратегічно важливим продуктом. IIÏ видобуток, забезпечення нею населення і навіть ціни на неї завжди були під прискіпливим державним контролем.

Торгівля сіллю, що мала дуже важливе значення для позбавленої власних соляних родовищ України, розвивалась в дуже несприятливих умовах. Незважаючи на це, чумацький промисел вже в XVI-XVII століттях досяг значних розмірів і відіграв важливу роль в економіці України. Так, в міру того, як відомості про солоників в документах XVI - першої половини XVII століття зустрічаються частіше, загадки про купців-солеторговців, які привозили сіль 3 півдня, майже зовсім зникають. Отже, з розвитком промислу чумаки повністю або майже повністю замінили купців у торгівлі сіллю на більшій частині території України. Відомий дослідник А. Баранович підрахував, що в Україні в 30-x роках XVII ст. налічувалось понад 4 млн. населення. Знаючи приблизно район, який чумаки забезпечували сіллю, можна гадати, що обсяг чумацької соляної торгівлі тоді досягав щонайменше 700 тис. пудів (11200000 кг. - Ю.С.) [2].

Регулярну торгівлю продуктами свого господарства з усіма сусідніми країнами: Росією, Кримом, Туреччиною, Польщею проводили також Запорожці. Вони вивозили на продаж хутра, шкіри, вовну, худобу, коней, масло й олію, пшеницю, рибу. На Запорожжя привозили 
заморські вина й бакалію, горілку, хліб, лісові матеріали, оливу, ладан, зброю, порох, олово, сукно, бавовняні й шовкові тканини, сап'ян (фарбована тонка, м'яка шкіра найрізноманітніших кольорів - Ю.С.) та іншій крам. Особливе значення мав торг сіллю, яку везли з Криму: до самої Польщі вивозили запорожці щороку близько 1000 возів солі. Як засвідчив у 1767 р. запорозький депутат у Комісії для вироблення нових законів, на Запорожжі 5.000 людей жило виключно з соляного промислу. На правобережну Україну везли в основному сало, віск, рибу хутра, сіль, сир, гнали коней і худобу. 3 самого мита Запорожжя мало великі прибутки: в 1688 році на одному тільки перевозі в Переволочній запорозькі шафарі взяли на користь військового скарбу 12.000 крб. мита. Підраховуючи річний оборот запорозької торгівлі в XVIII ст., професор М. Слабченко оцінює його в 800-835 тисяч карбованців. Довіз переважав над вивозом. Щоб полегшити торговельні операції чужим купцям, 3 військового скарбу давались позики [3].

Предметами українського вивозу були: воли, шкіри, віск, сало, олія, щетина, вовна, горілка, тютюн, коноплі, риба, збіжжя, сіль, селітра, поташ, смола. Головними пунктами, де збиралися товари й вивозилися далі на експорт, були: Київ, Ніжин, Чернігів, Стародуб. Але за кордон ішли через руки українських купців не тільки продукти українського господарства: ішли туди товари, які привозилися в Україну зі сходу, наприклад, чай, перські килими й різні східні матерії.

Одним із найважніших предметів вивозу були воли. Їх збували великими партіями по кілька сотень, а то й по кілька тисяч і гнали до Бреслава (місто Вроцлав, Польща - Ю.С.), до Гданська, до Кролевця. Волів розводили в південній частині Гетьманщини, в теперішній Полтавщині. Які маси волів вигодовували там, де нам уявлення, наприклад, факт, що в 1735 році російський уряд реквізував на Гетьманщині 20.000 волів. В 1737 році реквізовано 44.000 волів, а 30.000 куплено за гроші. Після волів однією 3 найдохідніших статей українського торгу був тютюн, який ріс на місцевих українських плантаціях. Ці плантації розводили не тільки старшини, але й прості козаки. Окремі українські експортери продавали сотні пудів, тобто десятки тисяч кілограм тютюну. Поряд 3 тютюном також дохідною статтею торгу була горілка й збіжжя. Торговельні операції іноді виходили поза межі німецьких міст: $є$ відомості, що українські купці збували свій крам до Франції та Голландії [4] .

Аналіз стану чумацького промислу в першій половині XIX ст. показує, що чумацьке візництво і чумацька торгівля тоді ще відігравали важливу роль у розвитку економіки України. Проте, значення чумацького промислу протягом цього періоду змінювалось. Якщо до 
кінця 30-х початку 40-х років XIX століття чумацький транспорт за техніко-економічними показниками в основному відповідав потребам внутрішньої і зовнішньої торгівлі, в значній мірі сприяючи ії розвитку, то надалі уже не міг задовольняти набагато зрослі вимоги, які пред'являлися до нього щодо вартості обсягу, швидкості перевезень.

В той час, як в передових, в економічному відношенні, країнах США, Англії і Франції, що стали на шлях капіталістичного розвитку, транспорт швидко вдосконалювався відповідно до потреб економіки, зокрема, йшло будівництво залізниць, у Росії, в тому числі і в Україні, протягом першої половини XIX ст. в цьому напрямку було зроблено дуже і дуже мало.

3 кінця 30-х років XIX ст. становище почало швидко змінюватись. Інтенсивне розорювання степів привело до того, що вартість чумацького транспорту почала зростати, бо підвищились витрати чумаків на утримання волів у дорозі. В той же час за кордоном залізниці удосконалювались, що привело до значного скорочення залізничних тарифів. У 1846 році перевезення вантажів волами в Україні коштувало вже втричі дорожче, ніж доставка залізницями в Західній Свропі. Така швидка зміна становища $з$ транспортом показала багатьом купцям і поміщикам, що чумацьке візництво не могло вже забезпечувати дедалі зростаючих потреб торгівлі і що тільки залізниці $є$ більш досконалим видом транспорту.

Будівництво залізниць і дальший розвиток пароплавства остаточно відірвали чумацький промисел. Розбагатіла верхівка чумаків, переходячи частково в стан купців і промисловців, становила одну з груп сільської буржуазії, що почала формуватися ще в надрах феодальнокріпосної системи. Щодо чумаків-візників, то число їх значно скоротилося, і тепер вони наймалися для перевезення вантажів на зовсім близьку відстань.

\section{Література:}

1. Сокур Ю. В. Становлення торговельного права в Україні (історико-правовий аспект). Підприємництвво, господарство $і$ право. 2004. № 5. C. 53-57.

2. Слабєєв I. С. 3 історії первісного нагромадження капіталу на Україні (Чумацький промисел, його роль в соціально-економічному розвитку України XVIII - першій половині XIX ст.) К.: Наук. Думка. 1964. $138 \mathrm{c}$.

3. Слабченко М. Е. Очерки торговли и торгового капитализма Гетманщины в XVII - XVIII ст. Одесса.: ГИУ. 1923. 192 с.

4. Букатевич Н. І. Чумацтво на Україні. Одеса. 1928. 240 с. 